\title{
GAMIFIKASI BAHASA ARAB DENGAN MODEL BLENDED LEARNING
}

\author{
Eka Lutfiyatun ${ }^{1}$ \\ ${ }^{1}$ Sekolah Tinggi Agama Islam Nurul Iman Bogor, Indonesia \\ Email: ekalutfiyatun@gmail.com
}

\begin{tabular}{l|l|l}
\hline Received: November 2021 & Accepted: Desember 2021 & Published: Desember 2021 \\
\hline
\end{tabular}

\begin{abstract}
Learning Arabic in Indonesia is entering a new phase in line with the ongoing pandemic. Schools are allowed to hold limited face-to-face meetings with reduced class hours. In response to this, a blended learning model is applied by combining face-to-face learning models in class and at other times conducting online learning outside the classroom or at home. To help students achieve the objectives of learning Arabic, there are alternative technology-based learning methods, namely in the form of gamification by utilizing online or android-based games. The purpose of this study is to describe how educators apply gamification in blended learning. The method used in writing this article is a literature review that produces descriptive data from various research results on teacher experiences in gamification in blended learning. The results of the study show that various types of Arabic learning games have been developed and used by educators. The game allows students to practice language with a fun experience. This provides convenience and increases interest for students, so that learning objectives can be more effectively realized.
\end{abstract}

Keywords: Gamification, Arabic Language, Blended Learning

\begin{abstract}
Abstrak: Pembelajaran bahasa Arab di Indonesia memasuki fase baru seiring dengan pandemi yang sedang terjadi. Sekolah-sekolah diperbolehkan melakukan pertemuan tatap muka terbatas dengan pengurangan jam pelajaran. Menyikapi hal ini diberlakukan model blended learning dengan menggabungkan model belajar tatap muka di kelas dan di lain waktu melakukan pembelajaran daring di luar kelas atau di rumah. Untuk membantu peserta didik mencapai tujuan pembelajaran bahasa Arab, terdapat alternatif metode pembelajaran berbasis teknologi yaitu dalam bentuk gamifikasi dengan memanfaatkan game daring maupun berbasis android. Tujuan kajian ini adalah mendeskripsikan bagaimana pendidik menerapkan gamifikasi dalam blended learning. Metode yang digunakan dalam penulisan artikel ini adalah kajian literatur yang menghasilkan data deskriptif dari berbagai hasil penelitian tentang pengalaman guru dalam gamifikasi dalam blended learning. Hasil kajian menunjukkan bahwa beragam jenis game pembelajaran bahasa Arab mulai dikembangkan dan digunakan para pendidik. Game tersebut memungkinkan peserta didik dapat berlatih bahasa dengan pengalaman yang menyenangkan. Hal ini memberikan kemudahan serta menambah minat bagi peserta didik, sehingga tujuan pembelajaran dapat lebih efektif untuk diwujudkan.
\end{abstract}

Kata Kunci: Gamifikasi, bahasa Arab, Blended Learning 


\section{A. Pendahuluan}

Pembelajaran bahasa Arab saat ini memasuki tahap baru seiring dengan berlangsungnya pandemi Covid-19. Lebih dari tiga semester pembelajaran dilaksanakan secara daring dengan memanfaatkan media internet. Namun, mulai pertengahan Agustus 2021 sekolah sudah mulai melaksanakan pertemuan tatap muka terbatas. Peserta didik diperbolehkan belajar di kelas dengan kapasitas 50\% dari jumlah siswa. Selain itu, terdapat pengurangan waktu menjadi 30 menit untuk setiap jam pelajaran. Hal ini menjadikan durasi pembelajaran di kelas sangat terbatas. Untuk itulah sekolah menerapkan blended learning yang menggabungkan pembelajaran di kelas dan daring dengan memanfaatkan teknologi yang dapat diakses di rumah.

Blended learning merupakan integrasi pembelajaran konvensional di kelas dan pembelajaran berbasis daring untuk peserta didik yang sama dan di mata pelajaran yang sama. Jadi pada suatu waktu peserta didik belajar di kelas dan di waktu yang lain belajar atau latihan daring dengan bantuan media teknologi. ${ }^{1}$ Media daring digunakan sebagai penyempurna hasil belajar peserta didik. ${ }^{2}$ Dengan demikian receptive skill atau kemampuan menerima materi bahasa Arab lebih meningkat dan lebih efektif dalam melaksanakannya. ${ }^{3}$

Hal tersebut menjadi tantangan tersendiri bagi pendidik karena waktu belajar di kelas menjadi terbatas namun peserta didik harus tetap menguasai keterampilan berbahasa Arab. Biasanya sebelum pandemi di tingkat Madrasah Tsanawiyah pembelajaran bahasa Arab berlangsung selama 80 menit dan di Madrasah Aliyah adalah 90 menit. Namun dalam pertemuan tatap muka terbatas yang mulai berlaku di sekolah-sekolah, durasi pembelajaran bahasa Arab setiap minggu adalah 2 jam pelajaran atau 60 menit. ${ }^{4}$ Terdapat perbedaan durasi pembelajaran sebelum dan saat pandemi antara 20 hingga 30 menit. Padahal dalam waktu tersebut bisa digunakan sebagai penguatan atau latihan-latihan untuk meningkatkan keterampilan berbahasa Arab.

Menyikapi problematika tersebut dengan adanya pendekatan blended learning, pendidik melaksanakan penyampaian materi selama di kelas dan mengadakan latihan-latihan dan evaluasi pembelajaran secara daring dengan bantuan media digital, salah satunya adalah game online.

\footnotetext{
${ }^{1}$ Martha Cleveland-Innes dan Dan Wilton, Guide to blended learning (British Columbia: Commonwealth of Learning Press, 2018), 2.

${ }^{2}$ Josh Bersin, The blended learning book: Best practices, proven methodologies, and lessons learned (San Francisco: John Wiley \& Sons, 2004), 56.

3 Nur Hayati dan Mualim Wijaya, "Pengelolaan Pembelajaran Melalui Blanded Learning Dalam Meningkatkan Receptive Skill Peserta Didik di Pondok Pesantren," Palapa 6, no. 2 (2018): 16.

${ }^{4}$ Muhammad Genantan Saputra, "Catat Durasi Waktu Belajar Tatap Muka Untuk PAUD, SD Hingga SMA Di Jakarta," merdeka.com, 29 Agustus 2021, https://www.merdeka.com/jakarta/catat-durasi-waktu-belajartatap-muka-untuk-paud-sd-hingga-sma-di-jakarta.html.
} 
Fenomena pembelajaran berbasis game sering disebut dengan gamifikasi pembelajaran. Gamifikasi pembelajaran merujuk pada kata gamifikasi yang berarti menggunakan sistem berbasis game untuk memotivasi suatu tindakan, memperkenalkan pembelajaran, dan menyelesaikan masalah dalam suatu pembelajaran. ${ }^{5}$

Blended Learning dan gamifikasi merupakan sebuah konsep baru di kalangan pendidik sehingga perlu adanya pemahaman lebih lanjut mengenai konsep ini sehingga dapat diterapkan dengan maksimal. Diperlukan sinergi antara sekolah, pendidik, peserta didik, dan orang tua dalam mengawal dan melaksanakan model pembelajaran ini. Sehingga pendidik menjadi salah satu pemeran penting yang harus menelaah dan menganalisis berbagai contoh penerapan gamifikasi dalam blended learning yang sudah dilakukan oleh peneliti dan penggiat pendidikan yang lain untuk dapat dipelajari bagaimana langkah-langkah, kekurangan, dan kelebihannya.

Tujuan kajian literatur ini adalah untuk mendeskripsikan pengalaman para pendidik dalam menerapkan game dalam blended learning. Aspek yang menjadi fokus dalam artikel ini yaitu langkah-langkah pendidik dalam menerapkan gamifikasi pembelajaran bahasa Arab dengan model blended learning dan bagaimana evaluasinya. Manfaat kajian literatur ini adalah sebagai deskripsi gamifikasi dalam blended learning yang dapat diterapkan pendidik di sekolah.

\section{B. Kajian Teori}

Bagian ini memaparkan konsep gamifikasi yang dapat dimanfaatkan dalam pembelajaran bahasa Arab dan penerapan model blended learning.

\section{Gamifikasi Pembelajaran Bahasa Arab}

Gamifikasi pembelajaran merujuk pada kata gamification yang berarti menggunakan sistem berbasis game untuk memotivasi suatu tindakan, memperkenalkan pembelajaran, dan menyelesaikan masalah dalam suatu pembelajaran. ${ }^{6}$ Gamifikasi pembelajaran adalah memanfaatkan game baik daring maupun luring untuk meningkatkan kualitas pembelajaran dan memudahkan pendidik dan peserta didik dalam proses belajar mengajar.

Gamifikasi pembelajaran memiliki manfaat dan berpotensi untuk meningkatkan hasil pembelajaran apabila dirancang dan digunakan dengan baik dan adanya efek untuk memotivasi siswa dalam mengikuti pembelajaran. ${ }^{7}$ Hal ini tentunya dapat dimanfaatkan pendidik sehingga peserta didik tetap bermotivasi tinggi meskipun melaksanakan latihan maupun evaluasi mandiri

${ }^{5}$ Karl M. Kapp, The gamification of learning and instruction: game-based methods and strategies for training and education (San Francisco: John Wiley \& Sons, 2012), 8.

${ }^{6}$ Kapp, 8.

7 Darina Dicheva dkk., "Gamification in education: A systematic mapping study," Journal of Educational Technology \& Society 18, no. 3 (2015): 83. 
dari rumah, apalagi game pembelajaran juga menyediakan fitur multi players atau dimainkan dengan banyak pemain.

Ada enam fitur dalam game untuk pembelajaran yaitu users (pengguna) atau siswa, challenges/tasks atau tugas-tugas atau permainan yang harus diselesaikan oleh pengguna, points adalah akumulasi hasil yang diperoleh setelah menyelesaikan tugas, levels adalah tingkatan kesulitan yang semakin naik apabila pengguna tugas selesai, badges adalah hadiah atau bentuk pujian apabila pengguna berhasil, dan ranking of users atau peringkat pengguna setelah tugas dalam game selesai. ${ }^{8}$ Sehingga bisa dikatakan pemanfaatan game dalam pendidikan dapat menjadi opsi untuk situasi pendidikan saat ini.

\section{Blended Learning}

Blended learning merupakan model pembelajaran yang dapat digunakan sebagai alternatif di situasi pandemi. Model pembelajaran adalah sebuah pola untuk menyusun kurikulum dan bahan pembelajaran di kelas. ${ }^{9}$ Blended learning atau pembelajaran blended mencampurkan program pendidikan formal dan non-formal, penggabungan antara kegiatan pembelajaran tatap muka dengan pembelajaran dengan bantuan teknologi daring.

Model blended learning ialah gabungan dua lingkungan belajar. Di satu sisi, ada pembelajaran tatap muka di lingkungan tradisional, di sisi lain ada lingkungan pembelajaran terdistribusi melalui teknologi baru yang kemungkinan diperluas untuk distribusi komunikasi dan interaksi. ${ }^{10}$ Hal tersebut tentunya dapat menjawab permasalahan peserta didik terkait keterbatasan waktu belajar di sekolah dengan memanfaatkan media daring untuk latihan di rumah. Tahapan blended learning adalah penyajian materi oleh guru, pemberian latihan soal, penggunaan layanan internet untuk membantu pengerjaan latihan soal, dan pembahasan latihan soal.11

Pada dasarnya blended learning memilih teknik paling unggul untuk proses belajar. Istilah ini muncul saat masyarakat sadar dengan keunggulan dan keterbatasan pembelajaran daring berbasis teknologi digital. Teknologi digital tidak akan pernah dapat menggantikan kehadiran sosok pendidik di kelas untuk membina sikap dan perilaku peserta didik. ${ }^{12}$ Sehingga diperlukan pembelajaran tatap muka bersama pendidik. Interaksi tatap muka diterapkan untuk mengatasi keterbatasan dari pembelajaran daring. Untuk itulah dengan bantuan game untuk pembelajaran

\footnotetext{
${ }^{8}$ Kapp, The gamification of learning and instruction: game-based methods and strategies for training and education, 20.

${ }^{9}$ Rafiqah Rafiqah, “Pengembangan Perangkat Pembelajaran Berbasis Konstruktivisme,” 2013, 48.

10 Cleveland-Innes dan Wilton, Guide to blended learning, 2.

11 Cleveland-Innes dan Wilton, 79.

12 Dewi Salma Prawiradilaga, Wawasan teknologi pendidikan (Jakarta: Kencana Prenada Media Group, 2014), 276.
} 
dalam penerapan model blended learning dalam bahasa Arab dapat memaksimalkan keterampilan peserta didik berbahasa Arab meskipun waktu belajar di sekolah terbatas.

\section{Metode Penelitian}

Artikel ini adalah kajian literatur yang merupakan salah satu pendekatan dalam kajian kualitatif, daan bertujuan untuk menghasilkan data deskriptif. Desain kajian yang digunakan adalah kajian teks atau pustaka dengan menelaah konsep gamifikasi dalam blended learning. Data dikumpulkan dari berbagai literatur yang merupakan kumpulan laporan hasil penelitian karya tulis ilmiah terdahulu seperti skripsi, disertasi, jurnal, artikel, dan prosiding seminar dengan tema gamifikasi pendidikan dan blended learning.

Kajian ini menggunakan teknik dokumentasi dengan mengumpulkan data melalui berbagai dokumen tertulis, seperti buku-buku tentang pendapat dan teori, artikel, jurnal, dan laporan hasil penelitian. Waktu analisis data ini adalah bulan Oktober 2021. Teknik analisis data yang digunakan adalah teknik analisis konten (content analysis) dengan memanfaatkan prosedur untuk menarik kesimpulan yang sahih dari berbagai dokumen dan menemukan karakteristik pesan yang dilakukan secara objektif dan sistematis. Langkah selanjutnya adalah membandingkan antara satu tulisan dengan tulisan yang lainnya namun masih dalam bidang yang sama.

\section{Hasil dan Pembahasan}

Gamifikasi pembelajaran bahasa Arab dengan model blended learning menjadi salah satu upaya untuk membantu peserta didik dalam mencapai tujuan pembelajaran di masa pandemi seperti saat ini. Game adalah suatu jenis model permainan atau pertandingan. Game merupakan aktivitas terstruktur atau semi terstruktur yang biasanya dilakukan untuk fun dan kadang digunakan sebagai alat pembelajaran.13 Hasil penelitian menunjukkan bahwa terdapat pengaruh yang signifikan game online terhadap minat belajar siswa karena $r$ hitung yang diperoleh yaitu 0,659 sedangkan $r$ tabel 0,248 dengan signifikan 0,05.14 Minat belajar peserta didik bisa meningkat karena penyajian game yang menarik. Peserta didik tidak terasa sedang mengerjakan soal karena materi dan soal dikemas dengan sedemikian rupa.

Selain itu peserta didik juga dapat langsung mengevaluasi hasil latihan karena game menyediakan fitur review yang dapat diakses peserta didik. Hal ini tentunya memudahkan pendidik dalam mengevaluasi perkembangan peserta didik terhadap materi bahasa Arab yang sedang 2003), 87.

13 Muhammad Suyanto, Multimedia alat untuk meningkatkan keunggulan bersaing (Penerbit Andi,

14 Nurfadilah Ramdani, "Pengaruh Game Online Terhadap Minat Belajar Siswa kelas VI SDN Bawakaraeng 1 Kota Makassar” (Skripsi, Makassar, Universitas Muhammadiyah Makassar, 2018), 186. 
diajarkan, apalagi kalau jumlah peserta didik yang menjadi tanggung jawab terdiri dari banyak kelas paralel. Review latihan secara menyeluruh juga sudah disediakan oleh fitur game tersebut sehingga membantu peserta didik untuk langsung mengetahui di mana letak kesalahannya ketika menjawab. Namun, kekurangannya adalah karena game ini digunakan dalam blended learning untuk sesi di rumah, rentan gangguan seperti sinyal internet maupun ada peserta menerima bantuan dari orang lain ketika latihan sehingga perlu adanya kolaborasi antara pendidik dan orang tua dalam pengawasan.

Memasuki masa new normal atau kenormalan baru di mana peserta didik melaksanakan pertemuan tatap muka terbatas. Peserta didik melaksanakan pembelajaran di kelas dengan waktu yang terbatas dan di waktu yang lain sepulang sekolah dapat melanjutkan latihan-latihan dalam bentuk game pembelajaran daring yang sudah diinstruksikan oleh pendidik sebelumnya. Pembelajaran ini mulai digunakan karena dinilai efektif dengan situasi pandemi saat ini. Blended learning secara signifikan efektif meningkatkan kemampuan bahasa Arab. ${ }^{15}$ Penguatan materi dapat dilakukan pendidik di dalam kelas. Hal ini dimaksudkan supaya peserta didik tetap mendapatkan latihan-latihan untuk meningkatkan keterampilan berbahasa Arab.

Adapun langkah-langkah yang dapat diterapkan dalam rangka model pembelajaran tersebut adalah sebagai berikut.

1. Pendidik mempersiapkan materi yang akan digunakan untuk pembelajaran di kelas sesuai dengan alokasi waktu yang ditentukan.

2. Pendidik mempersiapkan materi berupa game online yang akan dimainkan peserta didik di rumah.

3. Pendidik menyampaikan materi dan melaksanakan pembelajaran di kelas dan memberikan arahan kepada peserta didik bagaimana mengerjakan latihan-latihan yang ada pada game online yang sudah disediakan.

4. Peserta didik mengerjakan latihan-latihan secara daring di rumah masing-masing.

5. Peserta didik dapat langsung melihat hasil latihannya sesuai dengan skor yang didapat beserta pembahasan-pembahasan soal yang sudah disediakan game tersebut secara otomatis.

6. Pendidik dapat mengawasi dari jarak jauh siapa saja yang sudah melakukan latihan di game dan menganalisis hasilnya dengan menggunakan fitur result yang disediakan oleh game tersebut.

${ }^{15}$ AlJohara Fahad Al Saud, “The Effect of Blended Learning on Children's Arabic Reading during Covid19 Quarantine," International Journal of Innovation, Creativity and Change 14, no. 1 (2021): 12. 
7. Ketika pertemuan tatap muka lagi di kelas, pendidik dan peserta didik melakukan refleksi terhadap kegiatan yang sudah dilakukan.

Saat ini banyak beredar media daring yang dapat digunakan dalam pembelajaran karena efektif, praktis, efisien, dan memudahkan komunikasi antara pendidik dan peserta didik. ${ }^{16}$ Dengan adanya game, peserta didik dapat merasakan pengalaman secara langsung dari berbagai emosi seperti perasaan ingin tahu, keliru dalam menjawab latihan soal, kecewa, hingga bahagia jetika dapat menyelesaikan semua latihan dengan baik. ${ }^{17}$ Seperti halnya penelitian yang dilakukan oleh Majid dan Huda ${ }^{18}$ mendapati hasil analisis masalah berupa peserta didik mengalami kesulitan dalam pembelajaran bahasa Arab dan adanya potensi sebesar $80 \%$ materi dapat diterima dengan bantuan pengajaran melalui cara bermain sambil belajar karena peserta didik dapat dapat melihat, mendengar, dan juga melalui interaksi. Hasil penelitiannya adalah berupa game yang meliputi reward, point, level, dan achievement yang menghasilkan peningkatan signifikan dalam pembelajaran bahasa Arab.

Peneliti lain juga melakukan penelitian terkait gamifikasi dalam pembelajaran bahasa Arab dengan memanfaatkan game Quizizz. Hasil penelitian menunjukan kenaikan nilai sebesar 27,22\% dengan hasil T-test adalah 0,018. Hal ini membuktikan bahwa gamifikasi pembelajaran bahasa Arab dengan memanfaatkan media daring Quizizz efektif dengan kategori medium untuk meningkatkan kemampuan kosakata peserta didik. ${ }^{19}$ Selain itu, ada beberapa kelebihan Quizizz dibandingkan dengan media daring lain yaitu membantu pendidik menyederhanakan isi pembelajaran dan memperoleh respon positif dari peserta didik, ${ }^{20}$ melatih konsentrasi, ${ }^{21}$ kejujuran dan kemandirian dalam mengerjakan latihan, serta pendidik lebih cepat mengetahui hasil data statistik tentang kinerja peserta didik. ${ }^{22}$ Game ini juga dapat diakses melalui komputer, laptop, maupun handphone.

Adapun kekurangan dari gamifikasi pembelajaran bahasa Arab berbasis daring adalah gangguan sinyal maupun spesifikasi perangkat yang kurang memadai untuk mengakses game ini,

16 Hasan Basri dkk., "Efektivitas Pemanfaatan Media Online Dalam Pembelajaran Di Masa Pandemi Covid-19," Tarbiyatuna: Jurnal Pendidikan Ilmiah 5, no. 2 (2020): 156.

17 Siti Rosilawati Ramlan, "Gamifikasi untuk Pembelajaran Bahasa.: Tinjauan Literatur Linguisti," dalam Prosiding Seminar Kebangsaan Pendidikan (Kuala Lumpur: Univesiti Sultan Zainal Abidin, 2018), 1286.

18 Haritsa Taqiyya Majid dan Sheila Nurul Huda, "Gamifikasi Pembelajaran Huruf Hijaiyah dan Bahasa Arab: Studi Kasus PAUD Terpadu Mutiara Yogyakarta," AUTOMATA 1, no. 2 (2020): 18-23.

19 Annindita Hartono Putri dkk., "Arabic Quizzes Game to Improve Arabic Vocabulary," Tanwir Arabiyyah: Arabic As Foreign Language Journal 1, no. 1 (2021): 53.

20 Nisa Tazkiya Al Munawaroh, "The Use of Quizizz Online Software in the Evaluation of Arabic Learning," ALSUNIYAT: Jurnal Penelitian Bahasa, Sastra, dan Budaya Arab 4, no. 1 (2021): 12.

${ }_{21}$ Suo Yan Mei, Suo Yan Ju, dan Zalika Adam, "Implementing Quizizz as game based learning in the Arabic classroom," European Journal of Social Science Education and Research, 2018, 11.

22 Nafi' Mukharomah, "Penggunaan Aplikasi Quizizz sebagai Media Penilaian Berbasis Daring di MI Al Muqorrobiyah," Jurnal WANIAMNEY: Journal of Islamic Education E-ISSN 2, no. 1 (2021): 9. 
Meskipun pada dasarnya Quizizz mudah digunakan, namun perlu adanya pengawasan dari orang tua dan pendidik secara berkala. Sehingga kolaborasi pendidik dan orang tua dalam mengawasi jalannya gamifikasi pembelajaran dengan model blended learning sangat penting untuk dapat menanggulangi gangguan-gangguan yang ada.

Selain itu Dian Ahkam Sani ${ }^{23}$ menerapkan tiga macam game berbasis android yang dapat digunakan oleh peserta didik di tingkat dasar. Pertama adalah game berbasis flash card dua dimensi untuk meningkatkan kemampuan kosakata dengan mencocokkan dua kartu digital yang berisi kosakata bahasa Arab dan gambar yang mengilustrasikan kosakata tersebut. Berikut adalah langkah-langkah yang dilakukan: (1) Peserta didik diberikan 6 pasang gambar. Gambar pertama adalah kosakata bahasa Arab dan gambar kedua adalah ilustrasi arti; (2) Timer dan skor ditampilkan di bagian atas; dan (3) Peserta didik menyatukan gambar dengan cara menarik gambar ilustrasi menuju kata yang sesuai. Gambar 1 merupakan tampilan dari game flashcard.

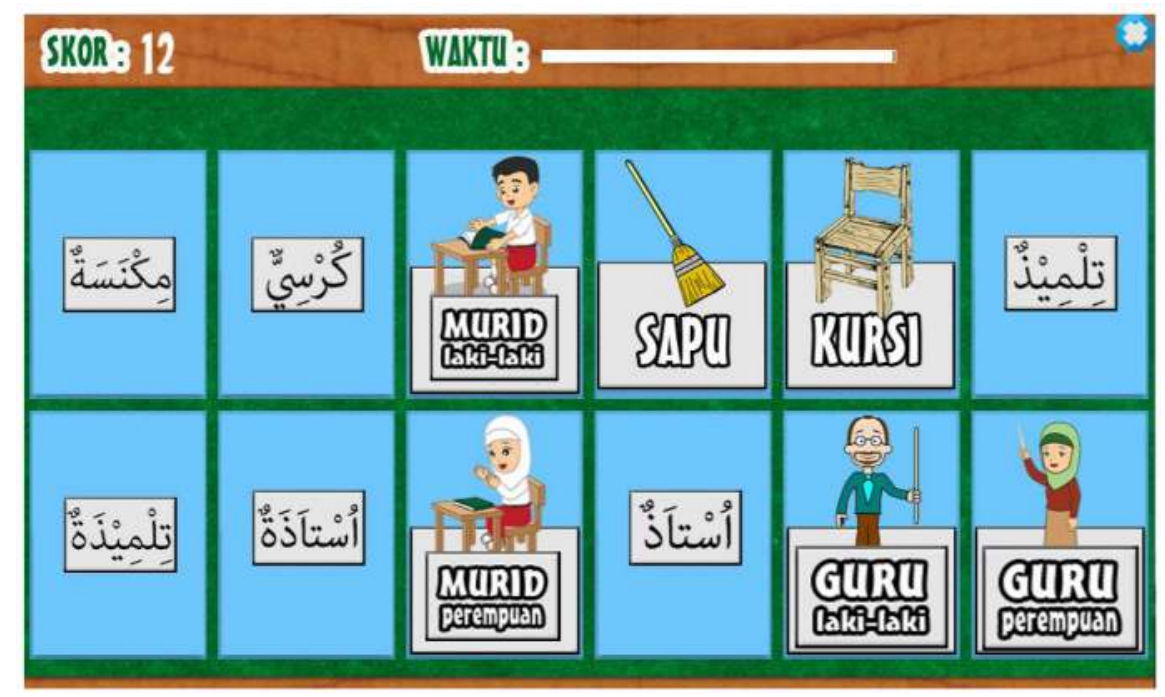

Gambar 1. Tampilan game flashcard 24

Kedua, adalah game puzzle dengan menyusun kata sesuai dengan gambar yang ada. Sedangkan game ketiga yang menarik adalah Role Playing Game (RPG) yang didesain seperti permainan petualangan dengan adanya 4 level permainan. Hal ini dapat dilihat sebagaimana tampilan pada gambar 2. Peserta didik mendapatkan misi yang harus diselesaikan berupa menjawab pertanyaan yang diberikan oleh ikon raja. Pertanyaan tersebut berupa kosakata bahasa Arab dan peserta didik diminta memilih arti kata yang tepat. Setelah selesai peserta didik akan

23 Dian Ahkam Sani, "Efektifitas Aturan Main Untuk Game Edukasi Kosakata Bahasa Arab Berbasis Mobile" (Dissertation, Institut Teknologi Sepuluh Nopember, 2017), 32-50.

24 Sani, 34. 
langsung mengetahui skor permainan yang dapat dijadikan sebagai bahan evaluasi.25 Hasil pengujian uji T adalah 2,48 efektif untuk meningkatkan hasil belajar bahasa Arab dan dapat melatih ketangkasan, logika, serta kecerdasan.

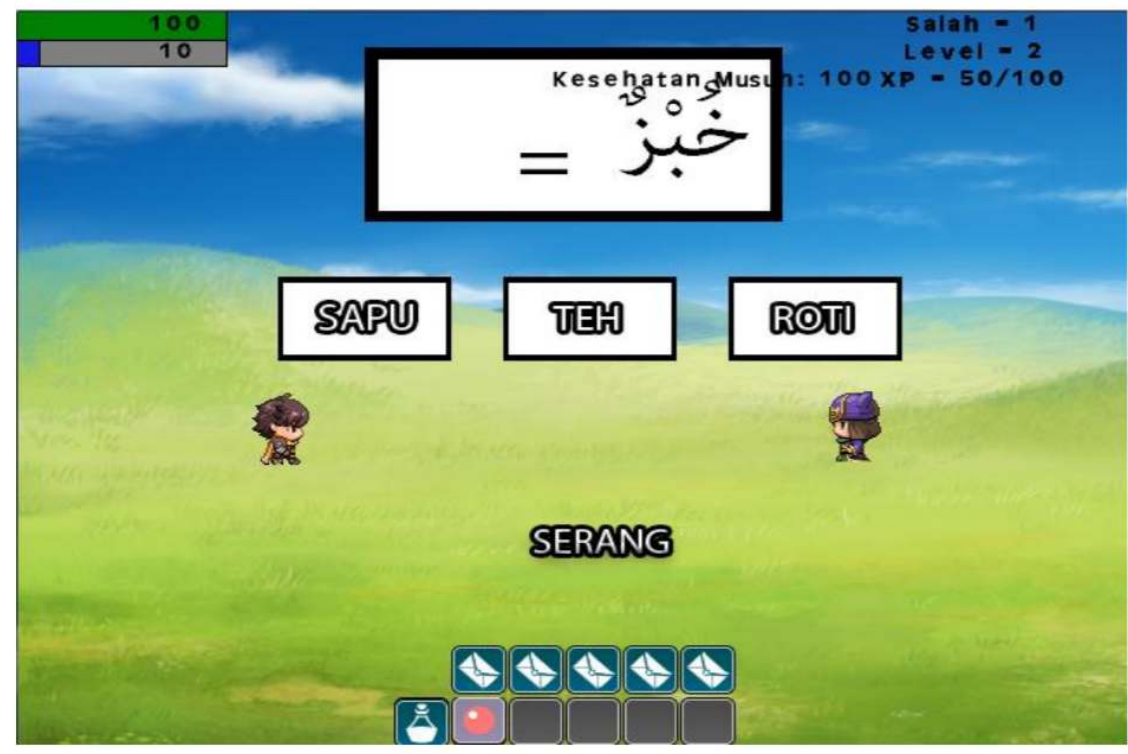

Gambar 1. Tampilan game Role Playing Game (RPG) ${ }^{26}$

Selain itu, penelitian lain yang memanfaatkan game berbasis android adalah yang dilakukan oleh Rahmatullah. ${ }^{27}$ Penelitian ini mengembangkan gamifikasi pembelajaran bahasa Arab untuk meningkatkan hasil belajar dalam materi kata kerja, kata benda, kata bantu, dan disertai latihanlatihan berupa pilihan ganda. langkah yang bisa dilaksanakan adalah: (1) Peserta didik harus menginstal aplikasi yang diberikan pendidik, (2) peserta didik login dengan nama user dan password yang telah dibuat sebelumnya, (3) di dalam game, peserta didik dapat secara mandiri belajar berbagai kosakata sesuai tema, (4) latihan bisa dilakukan dengan mengklik menu latihan, (5) setelah selesai, peserta didik dapat melihat hasil latihan beserta nilai yang secara otomatis terakumulasi dari jumlah benar yang dijawab.

Dari kedua penelitian di atas, dapat diketahui bahwa game berbasis android mempunyai kelebihan dan kekurangan. Kelebihanya adalah peserta didik dapat secara mandiri belajar dan mengerjakan latihan di rumah dan langsung dapat mengetahui perkembangan kemampuan diri sendiri terkait materi yang diajarkan. Kelebihan lain adalah penggunakan android memudahkan

25 Sani, 37.

26 Sani, 35.

27 Nova Ardhiansyah Rahmatullah, Aulia Paramita, dan Herlinda Herlinda, "Perancangan Aplikasi Pembelajaran Bahasa Arab Berbasis Android," dalam Semnas Ristek (Seminar Nasional Riset dan Inovasi Teknologi), vol. 5, 2021, 409-14. 
peserta didik dapat belajar di manapun. Namun ada juga kekurangannya yaitu karena berbasis aplikasi yang diinstal di handphone maka perangkat harus mendukung dan rentan kerusakan file aplikasi ketika file tersebut instal ke handphone.

Berdasarkan pengalaman para pendidik yang sudah mengimplementasikan gamifikasi pembelajaran bahasa Arab dengan model blended learning tentunya ada kelebihan dan kekurangannya baik secara teknis maupun dibutuhkan pengawasan lebih dari pendidik dan orang tua. Namun model pembelajaran seperti ini dirasa paling cocok dalam situasi pandemi seperti saat ini di mana peserta didik terbatas waktunya untuk belajar di kelas sehingga dibutuhkan penguatan dalam sesi daring yang bisa dilakukan di rumah dengan bantuan game daring maupun android.

\section{E. Kesimpulan}

Situasi pandemi seperti saat ini menjadikan pendidik lebih supaya bisa lebih memanfaatkan gamifikasi pembelajaran bahasa Arab dengan model blended learning sesuai dengan instruksi pemerintah bahwa peserta didik dikurangi jam belajar di sekolah dan bisa dilanjutkan dengan penguatan latihan-latihan secara daring di rumah. Ada beberapa opsi yang bisa dipilih oleh pendidik. Contohnya adalah gamifikasi pembelajaran dengan memanfaatkan game online yang berisi latihan-latihan bahasa Arab yang bisa dikerjakan secara daring di rumah masing-masing baik menggunakan komputer, laptop, maupun handphone. Contoh lain adalah dengan memanfaatkan game berbasis android yang dapat diakses melalui handphone peserta didik masing-masing. Kelebihan dari gamifikasi pembelajaran bahasa Arab adalah dalam hal efisiensi dan kemudahan akses asalkan koneksi internet memadai, Namun beberapa kekurangan juga perlu menjadi perhatian seperti daya dukung perangkat yang kurang memadai dan dibutuhkan kerjasama pendidik dan orang tua dalam pengawasan kegiatan.

\section{Daftar Rujukan}

Al Munawaroh, Nisa Tazkiya. (2021). "The Use of Quizizz Online Software in the Evaluation of Arabic Learning." ALSUNIYAT: Jurnal Penelitian Bahasa, Sastra, dan Budaya Arab 4, no. 1: 29-46.

Al Saud, AlJohara Fahad. (2021). “The Effect of Blended Learning on Children's Arabic Reading during Covid-19 Quarantine." International Journal of Innovation, Creativity and Change 14, no. 1.

Basri, Hasan, Lely Fathiyatus Sa'diyah, Siti Nur Khasanah, dan Danial Hilmi. (2020). "Efektivitas Pemanfaatan Media Online Dalam Pembelajaran Di Masa Pandemi Covid-19." Tarbiyatuna: Jurnal Pendidikan Ilmiah 5, no. 2: 145-58.

Bersin, Josh. (2004). The blended learning book: Best practices, proven methodologies, and lessons learned. San Francisco: John Wiley \& Sons. 
Cleveland-Innes, Martha, dan Dan Wilton. (2018). Guide to blended learning. British Columbia: Commonwealth of Learning Press.

Dicheva, Darina, Christo Dichev, Gennady Agre, dan Galia Angelova. (2015). "Gamification in education: A systematic mapping study." Journal of Educational Technology \& Society 18, no. 3: 75-88.

Hayati, Nur, dan Mualim Wijaya. (2018). "Pengelolaan Pembelajaran Melalui Blanded Learning Dalam Meningkatkan Receptive Skill Peserta Didik di Pondok Pesantren." Palapa 6, no. 2: 118.

Kapp, Karl M. (2012). The gamification of learning and instruction: game-based methods and strategies for training and education. San Francisco: John Wiley \& Sons.

Majid, Haritsa Taqiyya, dan Sheila Nurul Huda. (2020). "Gamifikasi Pembelajaran Huruf Hijaiyah dan Bahasa Arab: Studi Kasus PAUD Terpadu Mutiara Yogyakarta." AUTOMATA 1, no. 2.

Mei, Suo Yan, Suo Yan Ju, dan Zalika Adam. (2018). "Implementing Quizizz as game based learning in the Arabic classroom." European Journal of Social Science Education and Research.

Mukharomah, Nafi'. “Penggunaan Aplikasi Quizizz sebagai Media Penilaian Berbasis Daring di MI Al Muqorrobiyah." Jurnal WANIAMNEY: Journal of Islamic Education E-ISSN 2, no. 1 (2021).

Prawiradilaga, Dewi Salma. (2014). Wawasan teknologi pendidikan. Jakarta: Kencana Prenada Media Group.

Putri, Annindita Hartono, Fira Eka Permatasari, Athiyah Laila Hijriyah, dan Lailatul Mauludiyah. (2021). "Arabic Quizzes Game to Improve Arabic Vocabulary." Tanwir Arabiyyah: Arabic As Foreign Language Journal 1, no. 1.

Rafiqah, Rafiqah. (2013). Pengembangan Perangkat Pembelajaran Berbasis Konstruktivisme. Makassar: Alaudin University Press.

Rahmatullah, Nova Ardhiansyah, Aulia Paramita, dan Herlinda Herlinda. (2021). "Perancangan Aplikasi Pembelajaran Bahasa Arab Berbasis Android." Dalam Semnas Ristek (Seminar Nasional Riset dan Inovasi Teknologi), Vol. 5.

Ramdani, Nurfadilah. (2018). "Pengaruh Game Online Terhadap Minat Belajar Siswa kelas VI SDN Bawakaraeng 1 Kota Makassar.” Skripsi, Universitas Muhammadiyah Makassar.

Ramlan, Siti Rosilawati. (2018). "Gamifikasi untuk Pembelajaran Bahasa.: Tinjauan Literatur Linguisti." Dalam Prosiding Seminar Kebangsaan Pendidikan. Kuala Lumpur: Univesiti Sultan Zainal Abidin.

Sani, Dian Ahkam. (2017). "Efektifitas Aturan Main Untuk Game Edukasi Kosakata Bahasa Arab Berbasis Mobile." Dissertation, Institut Teknologi Sepuluh Nopember.

Saputra, Muhammad Genantan. (2021). "Catat Durasi Waktu Belajar Tatap Muka Untuk PAUD, SD Hingga SMA Di Jakarta." merdeka.com, 29 Agustus 2021. https://www.merdeka.com/jakarta/catat-durasi-waktu-belajar-tatap-muka-untuk-paudsd-hingga-sma-di-jakarta.html. 
Eka Lutfiyatun

Suyanto, Muhammad. (2003). Multimedia alat untuk meningkatkan keunggulan bersaing. Penerbit Andi. 